Edukacja Dorostych 2020, $n$ r 1

ISSN $1230-929 \mathrm{X}$

http://dx.doi.org/10.12775/ED.2020.006

\author{
Magdalena Giercarz-Borkowska
}

ORCID 0000-0002-3097-4573

\title{
MIĘDZY PRACĄ ZAWODOWA \\ A EDUKACJĄ DZIECI - SYTUACJA ZAWODOWA RODZICÓW EDUKUJĄCYCH DOMOWO
}

\begin{abstract}
Słowa kluczowe: edukacja domowa, rodzice, kobieta, matka, kariera.
Streszczenie: Artykuł dotyczy wyborów między karierą a wychowaniem dzieci, jakich dokonują rodzice edukujący domowo, którzy rezygnując z korzystania ze szkół, muszą zapewnić dzieciom całodobową opiekę. Przedstawia wyniki badań jakościowych przeprowadzonych w Polsce (2012-2019) metodą wywiadu narracyjnego oraz etnografii wirtualnej. Koncentruje się na matkach-edukatorkach, ponieważ kobiety są bardziej zaangażowane w edukację dzieci. Zrekonstruowana sytuacja zawodowa współczesnych homeschoolerek pozwala wpisać je w dwa dyskursy macierzyństwa: matkowanie („,momism”) i supermatki („superwoman”). Kobiety te, niezależnie od tego, czy podejmują pracę, czy koncentrują się wyłącznie na edukacji domowej, łączy jednoczesne poczucie zmęczenia i szczęścia. Ojcowie nie rezygnują z pracy z powodu edukacji domowej, choć najczęściej pracują na etatach. Popularny wśród polskich rodzin homeschoolingowych charakter zatrudnienia to: działalność gospodarcza, wolny zawód, praca zdalna. Wśród uczestników badań nie dominował tradycyjny model rodziny, najczęściej oboje rodzice byli aktywni zawodowo.
\end{abstract}

Idee pedagogiczne, którymi interesują się rodzice XXI wieku to m.in. leśne przedszkola, pedagogika Montessori oraz edukacja domowa. Większość jest oferowana przez niepubliczne placówki oświaty. Edukacja domowa jest jedyną koncepcją do zastosowania indywidualnego: nie może być zrealizowana inaczej niż przez rezygnację z pomocy państwowych instytucji. Wiedza o homeschoolingu rozprzestrzenia się szybko dzięki mediom społecznościowym, a decyzje o uczeniu (się) dzieci poza szkołą zapadają współcześnie nieporównywalnie częściej niż kilkanaście lat temu.

Łączenie wychowania dzieci z pracą zawodową jest jednym z problemów współczesnego rodzicielstwa. Jest on szczególnie aktualny w rodzinach edukacji domowej, które nie mogą (i nie chcą) skorzystać z opiekuńczej funkcji systemu 
oświaty. Najsilniej dotyczy rodzin z dziećmi w pierwszych latach szkoły, bo decyzja o edukacji domowej oznacza wtedy konieczność zapewnienia dziecku całodobowej opieki. Wątpliwości dotykają głównie matek, ponieważ to one najczęściej są rodzicem, który w większym wymiarze czasowym opiekuje się dzieckiem i zajmuje jego edukacją, i to je społeczeństwo obarcza odpowiedzialnością za wychowanie. Jak połączyć rolę edukatora domowego z zarabianiem na życie? Co motywuje rodziców do określonych wyborów? Jak czują się wobec poczynionych rozstrzygnięć?

\section{Od „matki-Polki” do „supermatki” - edukatorki domowe}

Rozważania związane z łączeniem ról rodzicielskich i zawodowych podejmowane są w kulturze i piśmiennictwie częściej odnośnie do matek niż do ojców. Obowiązuje normatywny wzorzec matki, którego wypełnienie jest społecznie oczekiwanym zadaniem kobiety. Zwykle też elementem oceny kobiet jest stopień „poświęcania się” w realizacji tego wzorca.

Modyfikacje wizerunku współczesnej kobiety-matki można prześledzić w literaturze (Sikorska, 2012). Ukształtowany w czasach zaborów wzorzec „,matki-Polki”, poświęcającej się dziecku, rodzinie i ojczyźnie, ewoluował. Czasy PRL-u „dołożyły” do modelu idealistyczno-heroicznego pracę zawodową, rozumianą w kategoriach dobra narodu i utrzymania rodziny. Kobieta miała być nie tylko pełną poświęcenia matką, ale też wydajną pracownicą, która ma siłę podołać i obowiązkom domowym, i zawodowym. Współczesność rozbudowała ten powinnościowy wzorzec o kolejne elementy, w tym ideologię intensywnego macierzyństwa. „Bycie matką” ma być urefleksyjnione - to nie jest tylko rola naturalna, ma być przemyślana i nieustannie autoewaluowana (Olcoń-Kubicka, 2009). Dzisiejsza „supermatka” ma wykonywać wszystkie te obowiązki, a przy tym być zadbana, uśmiechnięta i z listą sukcesów zawodowych (Sikorska, 2012). Kobieta-matka ma być po prostu wieloczynnościową kobietą szczęśliwą. Ciekawe jest, że kobiety same ,poganiają się" w biegu o ten tytuł, kreując nierealne wizje rodziny w mediach społecznościowych. Równolegle polskie matki nie chcą dłużej żyć w terrorze mitycznego symbolu (Mróz, 2014). Na marginesie dominujących oczekiwań rysuje się model „matki wystarczająco dobrej” (Samsel, 2015), odciążający kobiety z wielu presji i poczucia winy. Wydaje się on jednak zarezerwowany dla nielicznych (Sikorska, 2012).

Dla pełnienia roli rodzica istotne są uwarunkowania związane z rynkiem pracy. O ile ojcostwo nie koliduje z oczekiwaniami pracodawców co do roli pracownika - który ma być dyspozycyjny i podporządkowany interesowi firmy, o tyle społeczne wyobrażenia modelu matki są z nimi rozbieżne: od matki oczekuje się, że wycofa się z życia zawodowego albo je ograniczy do czasu aż dziecko osiągnie wiek przedszkolny lub szkolny. Kobieta staje więc zawsze wobec wyboru, czy narazić się na społeczną dezaprobatę, wracając do pracy krótko po porodzie (Titkow, 
2007), czy narazić się na utratę pracy/stanowiska, gdy weźmie urlop wychowawczy. Długotrwała nieobecność jest też związana z ograniczeniem kariery i niższym wynagrodzeniem. Wobec spodziewanych konsekwencji niełatwo jest podjąć decyzję, która nie będzie okupiona poczuciem straty emocjonalnej i/lub zawodowej.

W Polsce działa niewiele rozwiązań służących rzeczywistym wyborom w omawianym obszarze. Rządowy program 500+ nie traktuje rodzin równo, jego założenia i ekonomiczno-społeczne skutki są kontrowersyjne. Wśród instrumentów zatrudnienia przyjaznych rodzinie są: czasowe ograniczenie etatu, elastyczny czas pracy, praca zdalna. By podnieść aktywność zawodową kobiet, trzeba wprowadzać je w szerszej skali (Bronk, 2015), bo wspieranie macierzyństwa realizowane jest jedynie w niektórych firmach $-88 \%$ zatrudnionych ma stałe godziny pracy (Balcerzak-Paradowska, 2015). Rozwiązania sporadyczne na rynku pracy nie mogą więc istotnie wpływać na decyzje podejmowane przez rodziców w Polsce. Wobec braku istotnych zmian na poziomie makro, ważne są mikrozmiany - dokonywane w tych warunkach osobiste wybory (Biskup, 2012). Uwarunkowania ekonomiczne i nacechowany wartościami kulturowy wzorzec matki potęgują dylematy. Żadne z rozwiązań przeciwstawnych (nie pracować, by wychowywać dziecko vs. pracować kosztem scedowania opieki na inne osoby czy instytucje) nie jest satysfakcjonujące. Konflikt ten bywa przedstawiany jako wojna dwóch wrogich plemion: „Pań Mamusiek” i „Pań Ambitnych” (Graff, 2014).

Jak w warunkach tej wojny zostać edukatorką domową? Rodzice zainteresowani tematem uczenia (się) dziecka poza szkołą mogą czerpać wiedzę o łączeniu homeschoolingu z życiem zawodowym z nielicznych źródeł literaturowych. Wzmaga to ich aktywność w mediach społecznościowych, gdzie wymieniają informacje i doświadczenia oraz wspierają się, nie znalazłszy zrozumienia w najbliższym otoczeniu (Bartnikowska, Garbula, 2017).

W wynikach dotychczas opisanych badań eksponowane są matki, zaś obraz ojca wyłania się w tle. Portret współczesnej polskiej edukatorki domowej zarysowała Katarzyna Kochan (2015). W badaniach z udziałem 28 kobiet praktykujących homeschooling określiła zespół cech matek, które wybrały kształcenie dziecka poza szkołą. Kochan wnioskuje, że edukatorka domowa to: mężatka w wieku 35-40 lat, z wyższym wykształceniem - niepracująca (82\%), ale mimo to ciesząca się dobrą sytuacją finansową (84\%), która wychowuje troje dzieci w rodzinie tradycyjnej, będącej dla niej najwyższą wartością. 86\% uczestniczek uznaje, że do ojca należy zapewnienie rodzinie bytu, rolą matki zaś jest być „strażniczką domowego ogniska". Matki wykonują większość prac domowych, poświęcając sobie jedynie 30 minut dziennie. Czują się spełnione w tej roli. Nie żałują, że nie pracują zawodowo, ich akceptowaną powinnością jest uwolnić męża od trosk życia codziennego.

Autorka nazywa te matki „bardzo specyficzną grupą”, której nie można przyporządkować do żadnej z 7 kategorii współczesnych kobiet, określonych przez Katarzynę Pawlikowską i Dominikę Maison (2014). Dostrzega ich cechy wspólne 
z kobietami opisanymi jako Rodzinne Panie Domu (nie pracują, realizują się w roli matki, żony i pani domu, wychowują większą liczę dzieci, nie skupiają się na własnym wyglądzie) oraz Niespełnione Siłaczki (dobrze wykształcone, najwyżej cenią rodzinę, poświęcają siły na zajęcia domowe). Homeschoolerki odróżnia od Rodzinnych Pań Domu wiek (są młodsze), sytuacja finansowa (lepsza) i wykorzystywanie nowych technologii (w większym stopniu), zaś od Niespełnionych Siłaczek - większa liczba dzieci, życie w małżeństwach, a nie związkach nieformalnych, a także czerpanie życiowej satysfakcji ze źródeł innych niż praca i wygląd. Kochan uogólnia wnioski i przedstawia ten model ze świadomością, że jej badania miały charakter fragmentaryczny.

Większej próby dotyczą wyniki sondażu, w którym uczestniczyło 305 rodziców, przy czym aż 84\% to matki. Badaczki stwierdziły, że większość rodzin edukacji domowej jest wielodzietna (57\%), jednak najczęściej wychowuje 2 dzieci (30\%). Ich wnioski potwierdzają, że najczęściej rodzicem zaangażowanym w edukację jest matka ( $82 \%$ odpowiedzi $\left.{ }^{1}\right)$, co jest zbieżne z wynikami Kochan. Ojcowie uczestniczą w edukacji domowej z reguły dzieląc obowiązki z matkami. Ojca jako zaangażowanego wskazało tylko $41 \%$ respondentów, a ponadto „nie częściej niż w 18\% rodzin" rodzicem odpowiedzialnym za edukację domową jest jedynie on (Joanna Bielecka-Prus, Anna Heleniak, 2018a, s. 142-150; Bielecka-Prus, Heleniak, 2018b, s. 203).

Autorki kwestionują rzekomą patriarchalność rodzin edukacji domowej, o której można byłoby - jak piszą - wnioskować na podstawie informacji, że niemal 1/3 badanych kobiet nie pracuje. Wobec faktu, że ponad 3/4 uczestniczek ma wyższe wykształcenie, twierdzą, że zajmowanie się edukacją przez matki nie jest przejawem dominacji ojca w rodzinie, ,ale wręcz przejawem trzeciej fali feminizmu" - gdyby kobiety te chciały, mogłyby pracować. Tezę tę uzupełniają wynikiem: ,niemal 70\% tych kobiet łączy obowiązki związane z edukacją dziecka z pracą zawodową" (Bielecka-Prus, Heleniak, 2018a, s. 150,164; 2018b, s. 203-204).

Na większych próbach prowadzono też inne badania, jednak na podstawie ich raportów trudno odtworzyć metodologię procesu badawczego (w tym dobór próby), a zatem wyników nie można ekstrapolować na całą populację. Pamiętając o tym ograniczeniu, można zauważyć jedynie, że wg Marzeny Zakrzewskiej pracuje $90 \%$ ojców i niemal 76\% matek edukujących domowo (wartość bliższa wynikom Bieleckiej-Prus i Heleniak, a zdecydowanie odległa od badań Kochan), a praca zawodowa kobiet najczęściej jest koniecznością (41\%; 2013, s. 72-78). Paweł Zakrzewski donosi zaś, że wśród matek-edukatorek pracuje zawodowo 51\%, a 75\% ankietowanych ojców uważa, że za utrzymanie rodziny odpowiedzialni powinni być oboje rodzice (2013, s. 169). Z wyników przedstawionych w pracach

Wartość na poziomie $82 \%$ w odniesieniu do takiego wniosku autorki podają na s. 203 i 150, jednak w innym miejscu (s. 164) podają wartość 75\%. Kwestia ta nie została wyjaśniona. 
Zakrzewskich nie można wysnuć spójnych wniosków. Wydaje się jednak, że model tradycyjny nie był popularny w badanej próbie edukatorów, a to zdecydowanie odbiega od wyniku przedstawionego przez Kochan, gdzie $82 \%$ matek nie podejmuje pracy zarobkowej.

Pozostałe dostępne wyniki badań rodzin edukacji domowej w Polsce wydają się w temacie artykułu marginalne ze względu na niemożność opisania zjawiska w odniesieniu do większej próby (badania Marka Budajczaka, 2004) lub zamysł autora (badania Marii Głowackiej, 2015). Ich wyniki pokrywają się jednak z prezentowanymi wyżej co do wykształcenia rodziców - w większości to wykształcenie wyższe. Parametr ten jest istotny dla omawianego zagadnienia.

\section{Sposób zrekonstruowania sytuacji zawodowej rodziców edukujących domowo}

Dylematy rodziców związane z godzeniem obowiązków zawodowych i homeschoolingu ujawniły się podczas prowadzonych przeze mnie badań edukacji domowej w kontekście dzieci zdolnych (Giercarz-Borkowska, 2019). Zdecydowałam się zatem obecnie - wobec nikłego rozpoznania w polskiej nauce aspektu pracy zawodowej rodziców w rodzinach homeschoolingowych - dołożyć do już istniejących prac fragment opisu, skonstruowany niejako na marginesie tamtych dociekań, których celem było opisanie zjawiska edukacji domowej.

Badanie zrealizowałam w jakościowej orientacji badawczej, stosując procedurę opartą na indukcji. Prowadziło ono do uzyskania wiedzy deskryptywnej, emancypacyjnej, która może służyć praktyce pedagogicznej, w tym rodzicom zainteresowanym homeschoolingiem. Zastosowany interpretatywny paradygmat badawczy umożliwił mi nie tylko przedstawienie takiej - interpretatywnej - perspektywy, ale też perspektywy krytycznej (głos osób uczestniczących w badaniach). Postawiłam m.in. następujące pytania badawcze: Czym jest edukacja domowa? Jak ją praktykują i jakie znaczenia nadają jej uczestniczący w niej ludzie? Odpowiedzi na nie poszukiwałam w badaniach biograficznych. Dane zbierałam, prowadząc wywiady narracyjne na terenie całej Polski w rodzinach, w których dzieci realizują obowiązek szkolny/nauki poza szkołą przynajmniej przez rok. Dorosłym zadawałam pytanie: Jakie są Pani/Pana doświadczenia związane z edukacją własnych dzieci? Wywiady prowadzone z dziećmi inicjowałam zaś pytaniem: Opowiedz mi, jak się uczysz? W przypadku młodszych dzieci stosowałam wywiad swobodny kierowany. Zebrany w ten sposób bogaty materiał badawczy pozwolił nie tylko odpowiedzieć na postawione wówczas pytania badawcze, ale dostarczył też danych, sprzyjających rekonstrukcji sytuacji zawodowej rodziców edukujących domowo, której staram się dokonać w tym artykule.

Dostęp do uczestników badań rozpoczęłam od posiadanych kontaktów i kontynuowałam metodą kuli śnieżnej oraz przez portal społecznościowy. Rodziny, których członkowie udzielili mi wywiadów, zamieszkiwały różne środowiska - od 
wielkomiejskich po niewielkie wsie. Wychowywało się w nich od 1 do 5 dzieci (średnio 3). Każdy z wywiadów przeprowadziłam w osobistym kontakcie z daną osobą, najczęściej w jej rodzinnym domu. Rodzice uczestniczący w badaniu mieścili się w przedziale 30-55 lat. Większość z nich miała wyższe wykształcenie (94,4\% matek i 66,7\% ojców). Wybory, jakich dokonali oni odnośnie do problemu łączenia pracy zawodowej z edukacją domową dzieci, zarysowałam podczas analizowania 49 wywiadów (18 matek, 6 ojców, 25 dzieci w wieku 7-19 lat) fragmenty niektórych $\mathrm{z}$ nich przytaczam $\mathrm{w}$ artykule.

W uzupełnieniu tak uzyskanych danych posłużyłam się obecnie metodą etnografii wirtualnej, która miała dla moich opisów charakter pomocniczy. W Internecie poszukiwałam wpisów dotyczących łączenia pracy zawodowej z homeschoolingiem, by zweryfikować wcześniejsze dane (triangulacja), których zbieranie nie było ukierunkowane na kontekst poruszony w artykule. Przeanalizowałam treść postów na portalu Facebook w grupie dla osób zainteresowanych edukacją domową (około 18 tysięcy, głównie rodzice praktykujący lub rozważający homeschooling). To jedna $\mathrm{z}$ wielu grup, w które mam bieżący wgląd. Od lat uczestniczę $\mathrm{w}$ tym środowisku w procesie stawania się wirtualnym tubylcem - pozwala mi to rozumieć badaną społeczność „od środka”, czym zbliżam się do mitu antropologa-kameleona, coraz bardziej realnego w wirtualnym świecie. „Tubylczość” sprzyja kontroli jednego z ograniczeń: zaufania do wiarygodności pozyskanych treści. Dane, które zgromadziłam w wyniku analizy postów, są spójne z pojawiającymi się $\mathrm{w}$ tej grupie od dawna i zbieżne $\mathrm{z}$ zebranymi w wywiadach $\mathrm{z}$ osobami o potwierdzonej tożsamości, które odwiedziłam w ich domach. Uznałam więc, że wykonana netnografia jest wiarygodna. Wieloletnia enkulturacja umożliwia mi też ocenę, które treści zamieszczone w grupie są reprezentatywne, a zatem istotne dla prowadzonego badania (Jemielniak, 2013).

$\mathrm{Z}$ netnografią wiąże się też trudność w anonimizowaniu danych. Na użytek artykułu korzystałam z grupy otwartej, w której wszyscy godzą się na to, że treść wpisów może być publicznie łączona z ich nazwiskiem. Stąd - choć staram się parafrazować te wypowiedzi, nie cytować - nie chronię tożsamości dyskutujących tam osób w takim stopniu, jak osób udzielających mi wywiadów. Podobne stanowisko etyczne podziela Dariusz Jemielniak (2013, s. 109-110).

\section{Wybory zawodowe rodziców edukujących domowo}

Choć wśród dorosłych uczestników moich badań narracyjnych zdecydowanie przeważały kobiety (75\%), to $25 \%$ udział mężczyzn jest wartością wyższą niż w innych badaniach. Spójne narracje matek i ojców, a także etnografia wirtualna zdecydowanie potwierdzają, że rodzicem bardziej zaangażowanym w edukację domową jest matka. Taki podział ról obecny był w edukacji domowej XVIII, XIX i XX wiecznej (Jakubiak, Winiarz, 2004) i jest kontynuowany. Ojcowie w tych rodzinach wspierają partnerki psychicznie i organizacyjnie, ale zajmują się głównie 
pracą zarobkową, a w odniesieniu do dzieci - częściej rekreacją niż edukacją, choć włączają się też w uczenie (się). Rodziny edukacji domowej nie różnią się w tym względzie od innych, więc wyniki badań tej grupy - podobnie do prezentowanych źródeł dotyczących rodzicielstwa i zarobkowania - będą koncentrowały się na kobietach.

Kobiety-matki od wieków były przekazicielkami wartości życiowych, religijnych i patriotycznych (Piotrowska-Marchewa, 2011). Podobnie współczesne edukatorki podkreślają często, że ciągłość i spójność wartości, w których wychowują potomstwo, jest dla nich cenniejsza niż praca zarobkowa. Wybór edukacji domowej w wielu rodzinach motywowany jest dążeniem do zapewnienia dziecku spójnego środowiska wychowawczego, co - zdaniem rodziców - nie byłoby możliwe, gdyby dzielili wychowanie ze szkołą. Można powiedzieć, że rodziny te rozumieją własną tożsamość rodzicielską i rodzinną jako „wspólnotę wrastania i wzrastania”, i dążą do jej tworzenia świadomie, godząc się czasem na poniesienie kosztów, jak rezygnacja matki z pracy zawodowej, czy obniżenie statusu materialnego rodziny:

To chodzi o wartości życiowe, tak? Pewne takie rzeczy, które nam się nie podobaja i nie chcemy, żeby nasze dziecko byto w taki sposób y..., no indoktrynowane $(\mathrm{R} 12, \mathrm{~m})$.

Ja po prostu rezygnuję z pracy, bo my oboje z mężem mamy takie zawody, że one wymagaja pracy poza domem $(\mathrm{R} 17, \mathrm{~m})$.

Proces podejmowania decyzji o edukacji domowej jest zwykle długotrwały, obejmuje całą rodzinę, składa się z poszukiwania informacji. Dla rodziców ważne są pytania o kwestie zawodowe i finansowe. Zastanawiają się, co dla edukacji domowej będą musieli zmienić w życiu. Jak w nowej sytuacji łączyć pracę i wychowanie? Czy z pracy trzeba zrezygnować?

Próbowatam na początku eksperymentalnie pracować, i uczyć dzieci w domu. Ale ... tak się nie da. [...] po prostu zatrudniam na swoje miejsce dyrektora, co zreszta bardzo niekorzystnie się odbiło [...]. Ale powiem szczerze, że niezależnie od tych problemów finansowych, które ja będę miała z racji swojej decyzji, jestem bardzo zadowolona z tego, że jestem z dziećmi. [...] Czyli musiałam się na coś zdecydować [...] pod tym kątem musieliśmy przemodelować swoje życie $(\mathrm{R} 16, \mathrm{~m})$.

Wątpliwości dotyczące zawodowo-finansowej sfery życia są powszechne zrekonstruowałam je w wywiadach i potwierdziłam metodą etnografii wirtualnej. Osoby skupione w grupie tematycznej często interesują się tym problemem. W ciągu dwóch lat poddanych analizie poszukiwano takich informacji co najmniej kilkukrotnie. Najczęściej wpisy zamieszczały matki noszące się z zamiarem 
podjęcia edukacji domowej. Posty były licznie komentowane. Niemal za każdym razem w dyskusji pojawiał się głos wskazujący, że temat jest często poruszany i odpowiedzi udzielano już wielokrotnie, a pytająca była odsyłana do poprzednich wątków. Ponadto wśród komentujących zwykle pojawiały się 2-3 osoby, które też deklarowały zainteresowanie tematem. Sięgnęłam również do postów starszych o kolejne dwa lata i wśród nich odnalazłam wpis o tożsamej tematyce. Także pod nim informowano autorkę, że kilka osób poruszało temat wcześniej. Można zatem przyjąć, że opisywany problem jest ,ciągle żywy”. Tą drogą rodzice zmierzają do znalezienia własnego rozwiązania.

Matki zamieszczały w tych postach pytania typu: Jak poradzić sobie finansowo? Czy trzeba zrezygnować z pracy, by prowadzić homeschooling? Z jakich form zatrudnienia korzystają rodzice, $w$ jakich godzinach pracują? Czy rozwijają się zawodowo?

\section{Charakter pracy rodziców}

Odpowiedzi udzielane w komentarzach przez osoby praktykujące już homeschooling (znów: najczęściej matki) ukazują spektrum rozwiązań, które zależą od preferencji i możliwości rodziny, w tym posiadanych kwalifikacji, charakteru wykonywanej pracy, aspiracji zawodowych, wieku i liczby dzieci, zasobów rodzinnych itd. Podobnie wiele sposobów godzenia edukacji domowej z zatrudnieniem mogę zrekonstruować z badań narracyjnych. Najwięcej osób, z którymi rozmawiałam, prowadziło działalność gospodarczą (72,3\%). Zajmowało się nią $38,9 \%$ matek i 33,4\% ojców. Wśród narratorek 33,3\% nie pracowało, 22,2\% wykonywało wolny zawód, a 5,6\% pracowało w niepełnym wymiarze. Najliczniejsze wśród ojców zatrudnienie na etacie $(55,6 \%)$ było łączone z każdą formą pracy matek, oprócz niepełnego etatu. Zatem nie jest tak, jak obawiają się internautki, że w przypadku pracy etatowej mężczyzny kobieta zawsze jest zmuszona pozostać w domu. Wolny zawód wykonywało 11,1\% ojców. Wśród matek nie było żadnej, która pracowałaby etatowo w pełnym wymiarze, podobnie jak żaden z ojców nie zdecydował się zrezygnować z życia zawodowego na rzecz zajmowania się domem i edukacją dzieci. Te wyniki wydają się charakterystyczne dla współczesnego polskiego środowiska homeschoolingowego - ,zdominowanego" przez matki, ale wspierane przez ojców:

U podstaw leży to, że my z mężem jesteśmy do tego razem. [...] I to jest fajne, bo ja bym sama tego $w$ życiu nie ogarnęła. [...] w ogóle nie ma szans, nie dałabym $\operatorname{rady}(\mathrm{R} 4, \mathrm{~m})$.

W analizie charakteru zatrudnienia rodziców realizujących edukację domową (netnografia) na pierwszy plan wysuwają się: wolne zawody i praca zdalna (programiści, tłumacze, publicyści, blogerzy, freelancerzy, inni) oraz działalność 
gospodarcza (placówki edukacyjne, szkoła rodzenia, agroturystyka, network marketing, usługi). Wydaje się, że duża reprezentacja osób mających wolne zawody zaobserwowana w etnografii ma dwojakie uzasadnienie:

- warunki wykonywania wolnego zawodu sprzyjają organizowaniu edukacji domowej;

- edukację domową częściej wybierają ludzie ceniący wolność, a zatem tacy, którzy chętnie pracują w zawodach dających samodzielność. Jedna z matek podkreśla, że praca etatowa i chodzenie do szkoły mają podobne rygory, więc ona - osoba wysoko waloryzująca wolność - wybrała dla siebie wolny zawód, a dla dziecka homeschooling. Postawa ta cechuje większą grupę rodziców edukujących domowo.

Podobnie można interpretować liczną reprezentację osób posiadających przedsiębiorstwa. Prowadzenie biznesu wymaga cech zbliżonych, jak u edukatorek/ edukatorów domowych (kreatywność, odpowiedzialność, odwaga, samodzielność, dobra organizacja). Paradoksalnie sprzyja mu brak obowiązków rodzicielskich, jednak to te właśnie obowiązki wydają się skłaniać rodziców do zarobkowania na własny rachunek, ponieważ pozwala to elastycznie dopasowywać czas do pełnionych ról rodzica i przedsiębiorcy (Balcerzak-Paradowska i in., 2011; Rembiasz, Siemieniak, 2018; Rollnik-Sadowska, 2010). Działalność gospodarcza jest często wskazywana w komentarzach jako praca jednego z rodziców (głównie ojca) w połączeniu z różnymi formami zatrudnienia drugiego - praca: etatowa, na zlecenie, w niepełnym wymiarze. Matki prowadzące działalność zajmują się zarobkowaniem w czasie, gdy dzieci śpią - we wczesnych godzinach porannych albo wieczorami. Podobnie godziny pracy ustalają pracownice zdalne, uzyskując najbardziej atrakcyjną część dnia na życie rodzinne. Wśród matek-przedsiębiorczyń jest żona marynarza, która na co dzień sama radzi sobie i z pracą, i z edukacją domową. Inne rozwiązania to rodzinne biznesy, dzięki czemu rodzice elastycznie łączą pracę i edukację, tworząc niepowtarzalny styl życia. Wyniki netnografii pokrywają się w tym zakresie z wywiadami. Natomiast dość silnie eksponowana w Internecie praca zdalna nie dotyczyła żadnej z rodzin w badaniach narracyjnych - być może niejakie znaczenie mają tu różne okresy prowadzenia badań (dane narracyjne: 2012-2016, dane wirtualne: 2016-2019).

Dość często matki podejmują pracę w niepełnym wymiarze (poza domem lub zdalnie), przy czym czasem zabierają dziecko do miejsca pracy. Treść dyskusji dotyczących tego sposobu skłania do ostrożności w interpretowaniu informacji pochodzących z Internetu - po części mogą pojawiać się tam propozycje rozwiązań wyobrażonych, zamiast praktykowanych. Rodziny homeschoolingowe korzystają też z pracy zmianowej obojga rodziców, która pozwala na wymienianie się w opiece nad dzieckiem, ale nie było rodziny z dziećmi w młodszym wieku szkolnym, w której obydwoje rodzice pracują na etatach poza domem (rodzice dzieci starszych - tak). W internetowych wpisach deklarowano zatrudnienie etatowe 
epizodycznie, zdecydowanie najrzadziej spośród wszystkich praktykowanych modeli - nawet w odniesieniu do ojców, czyli inaczej niż w badaniach narracyjnych.

Wyraźna przewaga rozwiązań związanych z prowadzeniem działalności gospodarczej, wykonywaniem wolnych zawodów i pracą zdalną nie przesądza, że nie można realizować homeschoolingu w innych warunkach zawodowych. Rodzice praktykujący go podkreślają, że każdy wybór jest możliwy, ale nie każda rodzina jest gotowa daną sytuację zaakceptować, zmodyfikować dotychczasowy tryb życia. Obok konkretnych form zatrudnienia w komentarzach wskazywano zatem także kierunki myślenia o organizowaniu edukacji domowej i wybory, jakich trzeba dokonać: zaangażowanie do pomocy członków rodziny, powierzenie opieki nad dzieckiem płatnej opiekunce/nauczycielowi, korzystanie z oferty zewnętrznej (domy kultury itp.), czasowe ograniczenie zatrudnienia lub całkowitą rezygnację z pracy jednej osoby. Równocześnie rodzice pisali o konieczności określenia priorytetów rozważenia w rodzinie, czy ważniejsze jest utrzymanie dotychczasowego poziomu ekonomicznego, czy edukacja domowa kosztem obniżenia oczekiwań finansowych.

\section{Matki niepracujące zawodowo}

Choć często w analizowanym materiale etnograficznym osoby dyskutujące przekonywały, że wolą skromniejsze życie w zamian za możliwość prowadzenia homeschoolingu (podobnie jak w badaniach Kochan), to rzadko reprezentowały rodziny, w których matki zrezygnowały z zarabiania. Inaczej w wywiadach narracyjnych - wg tych danych co trzecia matka nie pracuje. Nie zawsze jednak wynika to z edukacji domowej - decyzje o niej bywają wtórne wobec tych, dotyczących opiekowania się dzieckiem niepełnosprawnym lub urlopu wychowawczego. Wydaje się, że w zderzeniu z opinią publiczną te matki są okresowo w nieco „uprzywilejowanej" sytuacji, bowiem ich wybory są legitymizowane.

Istnieje jednak społeczna zgoda, że dziecko w wieku przedszkolnym/szkolnym jest gotowe, by pójść do placówki. Społeczeństwo stawia „supermatce” zadanie: czas do pracy! Co w sytuacji, gdy ona zignoruje to oczekiwanie i postanowi zostać $\mathrm{z}$ dzieckiem $\mathrm{w}$ domu?

Pracę matek w edukacji domowej można umieścić - wg pojęć feministek w zbiorze „niewidzialnej pracy kobiet”, traktując to zajęcie jako profesję należącą do „różowej strefy gospodarki” (Bielecka-Prus, Heleniak, 2018b, s. 204). Moje badania potwierdzają ustalenia, że matki te celowo i z gotowością przyjęcia konsekwencji rezygnują z pracy, by budować kapitał kulturowy dzieci. Niepracujące edukatorki domowe są świadome niepochlebnych opinii na swój temat (Olcoń-Kubicka, 2009) i wiedzą, że kobiety aktywne zawodowo cieszą się większym szacunkiem społecznym (Zdrojewska, 2012):

Nigdy nie pracowatam [...]. Ale spotecznie to ja nie jestem z tego powodu ubóstwiana. [...] Ja jestem pasożyt spoteczny, który żyje na cudzy koszt i nie wyrabia 
PKB. To jest dla mnie osobiście najtrudniejsze. [...] przez cała ogromna grupę ludzi jestem traktowana jak... właściwie to wrzód na dupie spoleczeństwa $(\mathrm{R} 17, \mathrm{~m})$.

Tradycyjny model rodziny jest obecny w moich badaniach narracyjnych, choć nie wybrzmiał $w$ wypowiedziach w Interencie. Być może matki, które świadomie rezygnują z roli zawodowej nie wypowiadały się pod tymi postami, stąd symboliczna liczba ich wpisów (3). Narratorka, żyjąca w małżeństwie tradycyjnym, mówi o pracy, zarabianiu i edukacji domowej:

Ja się z tym zmagam. U nas jest raczej taki podziat, że mąż zarabia. [...] Mą̇ $z$ dziewczynkami się bawi. Jeśli już. Na spacery, na wycieczki, na lody... U nas raczej mąż jest od przyjemności. [...] domem też się nie zajmuje [...] - mamy taki podziat patriarchalny. Na męża i żonę (R17, m).

Wydaje się, że - przy dużym zmęczeniu - edukatorki domowe nie mają poczucia poświęcania swojego życia dla potrzeb dziecka, akceptują nowe perspektywy, które pojawiły się wraz z jego urodzeniem (Ecler-Nocoń, 2016), oraz że są skłonne do pozostania w zmienionej perspektywie związanej z pracą i samorealizacją zawodową przez dłuższy czas:

Na razie ze względu na edukację zostaję, ale to ze względu na małe dzieci [...]. Ale czas szybko mija. Różnie się zastanawiamy, no, różnie myślimy jak to może być, prawda? Może być tak, że mąz nie będzie mógt pracować na przyktad. No to wtedy wróce do pracy. [...] nie wiem, jak będzie za pięć, dziesięć lat. Dzieci rosna. Może nie będę $w$ domu aż tak potrzebna. Bo na razie dla nas to jest optymalne, że ja jestem $w$ domu $(\mathrm{R} 18, \mathrm{~m})$.

\section{Samorealizacja a praca zawodowa i prowadzenie homeschoolingu}

W środowisku rodzin homeschoolingowych nie ma jednomyślnych wyborów. $\mathrm{W}$ większości rodzin z prezentowanych badań każde z rodziców pracuje zawodowo, co ma też związek z potrzebą samorealizacji. Bywa, że kwestia ta staje na drodze do edukacji domowej - rodzice, którzy nie są w stanie zrezygnować z (części) aktywności zawodowej, porzucają zamiar uczenia dziecka poza szkołą.

Kulturowo sformatowana tożsamość kobiety ma z założenia koncentrować się na rodzinie i domu. Homeschoolerki prezentują dwa stanowiska wobec samorealizacji w pracy:

1. Praca zawodowa jest ważna ze względu na własny rozwój - te matki traktują wychowanie dziecka i samorozwój jako wartości dopełniające się, spójnie tworzące ich tożsamość. Nie wyobrażają sobie, że miałyby porzucić zajęcia zawodowe z powodu edukacji domowej i wybierają rozwiązania, które pozwalają im działać w obu rolach. O pracy mówią zarówno w kategoriach pasji i ambicji, jak i w kategoriach finansowych; 
2. Praca zawodowa jest ważna, ale nie najważniejsza - te matki zestawiają opozycyjnie wartości wychowania i pracy, przekonane, że osobiste wychowywanie dziecka jest cenniejsze od rozwoju zawodowego. Wybierają rolę macierzyńską do czasu, aż uznają, że ich osobista opieka nie jest już konieczna. Nie rezygnują z planowania życia zawodowego, choć o pracy mówią raczej w kategoriach ekonomicznych i bliżej nieokreślonej przyszłości.

Edukatorki domowe zauważają, że wypełnianie obowiązków związanych z nową rolą przynosi im także osobiste korzyści rozwojowe. Być może niektórym zadania te kompensują brak wyzwań zawodowych i związanych z nimi emocjonalnych gratyfikacji, ponieważ - paradoksalnie - pozwalają przekraczać sferę prywatną i działać w ciekawym środowisku:

Mi nie przeszkadza, że nie chodze do pracy, bo... rozwijam się w innych dziedzinach. [...] I bardzo mi sie podoba ta edukacja domowa, że my sobie tak robimy to wszystko, wszystko jest takie... wszystko trzeba budować od poczatku, prawda? Ja budowatam domy, [NAZWA] budowatam. To tam też tak byto, prawda?, że nic nie było... czlowiek ma pusta kartkę i musi wszystko od początku, wszystko sam! [...] A tu też jest! Tu też jest taka pusta, prawda? Nic nie jest zorganizowane, wszystko musimy sami wypracowywać (R18, m).

Współczesne polskie homeschoolerki znajdują pola satysfakcji i samorealizacji w codzienności, a natura edukacji domowej sprzyja dostrzeganiu takich okazji. Mają niewiele czasu dla siebie, nawet jeżeli nie pracują zawodowo, jednak myślą o własnym rozwoju - mówią o tej potrzebie z tęsknotą. Odkładają ją na bliżej nieokreślony czas, z nadzieją, że nadejdzie, gdy wywiążą się z życiowej roli macierzyństwa. Mogę tu odwołać się również do narracji opublikowanej przez Kochan: „Nie oznacza to jednak, że rezygnuję z pasji lub rozwoju. Ciągle o tym myślę, ale właśnie teraz nie ma na to czasu" (2015, s. 163).

\section{Pracujący ojcowie, „supermatki” i matkowanie}

Trzeba wskazać, że niezależnie od roli, jaką rodzice stojący przed decyzją o homeschoolingu ustalą dla matki - ojciec nie rezygnuje z pracy zarobkowej. Domem i dzieckiem zajmuje się w ograniczonym zakresie.

Wybory kobiet nie są tak jednorodne. Można próbować wpisać je we współczesne dyskursy macierzyństwa, zrekonstruowane przez Agnieszkę Gromkowską-Melosik (2017), przy czym dyskurs czwarty należy odrzucić. Wśród edukatorek domowych nie ma kobiet preferujących spełnienie zawodowe ponad rolę matki („childfree”). Nie dostrzegam też postaw kobiet, które można opisać trzecim dyskursem jako macierzyństwo w stylu maczo („,macho matering”). Nie odnalazłam matek, dla których dziecko jest „zadaniem” - atrybutem świadczącym o perfekcyjnym opanowaniu zadań życiowych i zawodowych, który dopełnia tożsamość kobiety sukcesu. Zatem również ten - uprzedmiotowiający dziecko - dyskurs macierzyństwa nie opisuje homeschoolerek. 
Zgromadzone dane pozwalają lokować życiowe wybory tych kobiet w obrębie dwóch dyskursów. Mniej popularnym, ale silnie obecnym wśród nich trendem jest matkowanie (,momism”). Edukatorki domowe żyjące w rodzinach patriarchalnych uznają macierzyństwo za najważniejszą społeczną misję i podporządkowują jej życie. W roli kobiety domowej znajdują spełnienie. W pewnym stopniu matki te wpisują się w ideologię intensywnego macierzyństwa. Koncentrują siły fizyczne i psychiczne na wychowaniu dziecka - dlatego rezygnują z pracy na rzecz edukacji domowej. Społeczną dezaprobatę dla swoich decyzji odczuwają jako krzywdzącą. Tym dyskursem można opisać około 1/3 edukatorek domowych.

Największa grupa matek dokonuje życiowych wyborów, które mieszczą się w dyskursie wyemancypowanej kobiety, zakładającym godzenie ról zawodowych i macierzyństwa (około 70\%). Interpretuję ich doświadczenia w pesymistycznym ujęciu tego dyskursu, które można utożsamiać z modelem supermatki („,superwoman"). Większość matek zajmuje się edukacją dzieci, pracując, co obciąża je i stresuje w dwójnasób. $Z$ dostępnych rodzajów zatrudnienia wybierają taki, który pozwoli najlepiej wykonywać jedne i drugie obowiązki. Na rynku pracy brakuje jednak instrumentów wspierających macierzyństwo, więc nie jest łatwo zarabiać na życie, rozwijać się zawodowo i jednocześnie dbać o rozwój dzieci. Dlatego homeschoolerki - podobnie jak inne matki pracujące i niepracujące (Sikorska, 2012, s. 113) - często mają poczucie winy, że zaniedbują którąś z ról. Kobiety te są odpowiedzialne i dążą do perfekcji - tym bardziej, że czują dodatkową presję i kontrolę otoczenia, ponieważ złamały społeczną umowę, według której dziecko idzie do szkoły. Mimo ogromnego zmęczenia są szczęśliwe.

\section{Wyemancypowanie czy powrót do przeszłości?}

Przedstawione wyniki uzupełniają istniejące już próby fragmentarycznego opisu konfliktu ról - zawodowej i rodzicielskiej - w edukacji domowej, który silniej dotyka kobiet niż mężczyzn. Ze względu na niesłabnący od wieków prymat matek w praktykowaniu tej idei jest to zjawisko istotne dla sprecyzowania jej współczesnego obrazu.

Moje interpretacje dążą do konstruowania jak najpełniejszego opisu polskiej edukacji domowej XXI wieku wspólnie z innymi osobami zainteresowanymi naukowo tym fenomenem. Edukatorki domowe, choć legitymują się głównie wyższym wykształceniem, nie pasują do wzoru kobiety po studiach, która odkłada macierzyństwo w obawie o utratę pozycji na rynku pracy (Młynarska, 2011). Jednak wydaje się nowe w stosunku do dotychczas opublikowanych wyników (Budajczak, 2004; Kochan, 2015), że wśród rodzin edukujących domowo nie dominuje model tradycyjny. Moim konkluzjom - co do opisu zawodowych dróg edukatorów domowych - bliżej jest do wyników Bieleckiej-Prus i Heleniak (2018a) oraz Zakrzewskiej (2013). Może to efekt zmieniającej się rzeczywistości społecznej i rozrastania się populacji rodzin edukacji domowej, a może niedostatecznych rozpoznań. 
Potrzebne są dalsze badania choćby z tego powodu, by odpowiedzieć na pytanie, czy rezygnacja z pracy to „wyemancypowanie... z nowoczesnego przymusu realizowania kariery zawodowej" (jak pisał Budajczak, 2004, s. 86), czy też „esencjonalistyczny powrót do przeszłości”, jak o dyskursie „matkowania” pisze Gromkowska-Melosik (2017, s. 104). Prezentowane przeze mnie interpretacje nie wyczerpują wszak tematu, a jedynie uzupełniają dotychczasową wiedzę co do sposobów radzenia sobie z homeschoolingiem i pracą.

To, co łączy matki-edukatorki domowe - niezależnie od tego, czy wybrały karierę i wychowanie dzieci, czy tylko wychowywanie dzieci - to jednoczesne poczucie zmęczenia i szczęścia oraz ograniczony udział w homeschoolingu ojców, którzy zachowują zatrudnienie i skupiają się na zapewnieniu bytu rodzinie.

\section{Bibliografia}

Balcerzak-Paradowska, B. (2015). Czas pracy jako instrument zatrudnienia przyjaznego rodzinie - polskie realia. Polityka Spoleczna, vol. 42, 4(493), s. 30-35.

Balcerzak-Paradowska, B., Bednarski, M., Głogosz, D., Kusztelak, P., Ruzik-Sierdzińska, A., Mirosław, J. (2011). Przedsiębiorczość kobiet w Polsce. Warszawa: PARP.

Bielecka-Prus, J., Heleniak, A. (2018a). Motywy podjęcia edukacji domowej w opinii rodziców. W: J. Bielecka-Prus (red.), Rodzina w edukacji domowej (s. 139-166). Warszawa: Wydawnictwo i Księgarnia Gotów.

Bielecka-Prus, J., Heleniak, A. (2018b). Sposób organizacji edukacji domowej. W: J. Bielecka-Prus (red.), Rodzina w edukacji domowej (s. 202-223). Warszawa: Wydawnictwo i Księgarnia Gotów.

Biskup, B. (2012). Role i niedole płci: kobieta pracująca w XXI wieku. Nowe Horyzonty Edukacji, nr 3, s. 16-17.

Bronk, A. (2015). O politykę rodzinną sprzyjającą pracy kobiet. Polityka Społeczna, $n r 7$, s. 21-25.

Budajczak, M. (2004). Edukacja domowa. Gdańsk: GWP.

Ecler-Nocoń, B. (2016). Macierzyństwo jako przełom i kapitał biograficzny. Problemy Opiekuńczo-Wychowawcze, $n r$ 4, s. 32-37.

Giercarz-Borkowska, M. (2019). Edukacja domowa jako alternatywa edukacyjna dla dzieci zdolnych. Wrocław: Wydawnictwo TeksTy.

Głowacka, M. (2015). Edukacja domowa a przemiany nowoczesności. Zoon Politykon, $n r 6$, s. 219-236.

Graff, A. (2014). Matki feministki. Warszawa: Krytyka Polityczna.

Jakubiak, K., Winiarz, A. (red.). (2004). Nauczanie domowe dzieci polskich od XVIII do $X X$ wieku. Bydgoszcz: Wydawnictwo Akademii Bydgoskiej.

Jemielniak, D. (2013). Netnografia, czyli etnografia wirtualna - nowa forma badań etnograficznych. Prakseologia, $n r$ 154, s. 97-116.

Kochan, K. (2015). Women-Home Educators. Pedagogika Rodziny, nr 5(2), s. 157-172.

Młynarska, M. (2011). Kiedy mieć dziecko? Jakościowe badanie procesu odraczania decyzji o rodzicielstwie. Zeszyty Naukowe Instytutu Statystyki i Demografii SGH, 11.

Mróz, L. (2014). Idealne i wściekłe. Newsweek Polska, $n r$ 22, s. 30-33.

Olcon-Kubicka, M. (2009). Indywidualizacja a nowe formy wspólnotowości. Warszawa: Wydawnictwo Naukowe Scholar. 
Pawlikowska, K., Maison, D. (2014). Polki. Spetnione profesjonalistki, rodzinne panie domu czy obywatelki świata? Warszawa: Wydawnictwo UW.

Piotrowska-Marchewa, M. (2011). Kobieta, rodzina i życie codzienne na ziemiach polskich w XIX wieku. Mówia Wieki, nr 3, s. 31-35.

Rembiasz, M., Siemieniak, P. (2018). Kształtowanie postaw przedsiębiorczych studentek w kontekście konfliktu roli rodzicielskiej i zawodowej. Nowe Horyzonty Wychowania, nr 17(43), s. 197-207.

Rollnik-Sadowska, E. (2010). Przedsiębiorczość kobiet w Polsce. Warszawa: Difin.

Samsel, A. (2015). Współczesna rodzina - cz. IV. Matka. Sygnał, nr 5, s. 17-19.

Sikorska, M. (red.). (2012). Raport Ciemna strona macierzyństwa. O niepokojach wspótczesnych matek. Warszawa: AXA.

Szczepańska, J. (2009). Raport o sytuacji kobiet w Polsce. Warszawa: CBOS.

Titkow, A. (2007). Tożsamość polskich kobiet. Warszawa: IFIS PAN.

Zakrzewska, M. (2013). Rola wychowawcza matki w edukacji domowej. Warszawa: Oficyna Wydawniczo-Poligraficzna „Adam”.

Zakrzewski, P. (2013). Rola wychowawcza ojca w edukacji domowej. Warszawa: Oficyna Wydawniczo-Poligraficzna „Adam”.

Zdrojewska, K. (2012). Kobieta aktywna zawodowo - zadania i role w świetle badań CBOS. Zmiana myślenia czy pogłębienie stereotypu? AEQUALITAS, nr 1.

\section{BETWEEN PROFESSIONAL WORK AND EDUCATION OF CHILDREN - THE PROFESSIONAL SITUATION OF HOME EDUCATING PARENTS}

Keywords: homeschooling, home education, parents, women, mother, career.

Summary: The article concerns the choices between career and the upbringing of children which home educating parents make, having to provide constant care for them since they decided not to send them to school. It presents the results of qualitative studies done in Poland (2012-2019) made by narrative interview and virtual ethnography. It focuses on mothers-educators, because women are more involved in the education of children. The reconstructed professional situation of modern homeschoolers allows one to enter them into two discourses of motherhood: momism and superwomen. Those women, regardless if they take up a job or focus on just homeschooling, are connected by a simultaneous feeling of tiredness and happiness. Fathers do not stop working because of home education, mostly working full time. Popular models of employment among Polish homeschooling families are business activity, freelance, remote work. Among the participants in the study the traditional family model did not dominate, most of the time both parents were professionally active.

Dane do korespondencji:

\section{dr Magdalena Giercarz-Borkowska}

Uniwersytet Opolski, Instytut Nauk Pedagogicznych,

ul. Oleska 48, 45-040 Opole

e-mail: magda.giercarz@wp.eu 